\title{
Pengaruh Kompetensi Profesional Terhadap Motivasi Kerja Guru SD di Gugus Rujakbeling Kecamatan Kebumen Kabupaten Kebumen
}

\author{
Ida Faridah \\ STAI An-Nawawi Purworejo \\ E-mail: faridahida242@gmail.com
}

\section{Article Info \\ Article History \\ Received: 2021-08-20 \\ Revised: 2021-09-10}

Published: 2021-10-05

Keywords:

Profesional Competence; Motivation;

Rujakbeling.

\begin{abstract}
This study aims to analyze the effect of professional competence on the work motivation of elementary school teachers in the Rujakbeling Cluster, Kebumen District, Kebumen Regency. The total population of 41 teachers and the sample used is 41 the entire population is used as a research sample, so it can be said that this research is a population study. Data was collected by using a questionnaire method. Validity test using Product Moment analysis technique and reliability test using Cronbach Alpha. Test the data analysis requirements using the normality test, linearity. Hypothesis testing using simple regression test The results of this study indicate: There is an influence of professional competence on the work motivation of elementary school teachers in the Rujakbeling Group, Kebumen District, Kebumen Regency with $\mathrm{t}$ count > from $t$ table $(2,611>2.023)$ and the magnitude of the effect is $14.9 \%$ known from $\mathrm{R}$ Square of 0.149 .
\end{abstract}

\begin{tabular}{l}
\hline Artikel Info \\
\hline Sejarah Artikel \\
Diterima: $2021-08-20$ \\
Direvisi: $2021-09-10$ \\
Dipublikasi: $2021-10-05$
\end{tabular}

Kata kunci: Kompetensi Profesional; Motivasi Kerja; Rujakbeling.

\section{Abstrak}

Penelitian ini bertujuan menganalisis pengaruh kompetensi profesional terhadap motivasi kerja guru SD di Gugus Rujakbeling Kecamatan Kebumen Kabupaten Kebumen. Jumlah populasi sebesar 41 guru dan sampel yang digunakan adalah 41 seluruh populasi dijadikan sebagai sampel penelitian, sehingga dapat dikatakan bahwa penelitian ini adalah penelitian populasi. Pengumpulan data dilakukan dengan metode angket. Uji validitas dengan teknik analisis Product Moment dan uji reliabilitas menggunakan Alpha Cronbach. Uji persyaratan analisis data menggunakan uji normalitas, linearitas. Pengujian hipotesis menggunakan uji regresi sederhana Hasil penelitian ini menunjukkan: Terdapat pengaruh pengaruh kompetensi profesional terhadap motivasi kerja guru SD di Gugus Rujakbeling Kecamatan Kebumen Kabupaten Kebumen dengan $\mathrm{t}$ hitung $>$ dari $\mathrm{t}$ tabel $(2,611>2,023)$ dan besarnya pengaruhnya sebesar 14,9\% diketahui dari R Square sebesar 0,149.

\section{PENDAHULUAN}

Guru merupakan komponen paling menentukan dalam sistem pendidikan secara keseluruhan, yang harus mendapatkan perhatian sentral, pertama, dan utama. Figur yang satu ini akan senantiasa menjadi sorotan strategis ketika berbicara masalah pendidikan, karena guru selalu terkait dengan komponen manapun dalam sistem pendidikan. Guru memegang peran utama dalam pembangunan pendidikan, kususnya yang diselenggarakan secara formal di sekolah. Guru juga sangat menentukan keberhasilan peserta didik, terutama dalam kaitannya dengan proses belajar mengajar. Guru merupakan komponen yang paling berpengaruh terhadap terciptanya proses dan hasil pendidikan yang berkualitas. Oleh karena itu, upaya perbaikan apapun yang dilakukan untuk meningkatkan kualitas pendidikan tidak akan memberikan sumbangan yang signifikan tanpa didukung oleh guru yang profesional dan berkualitas, Guru yang berkompetensi tidak hanya dituntut untuk menguasai bidang ilmu, bahan ajar, metode pembelajaran, memotivasi peserta didik, memiliki keterampilan yang tinggi, dan wawasan yang luas terhadap dunia pendidikan, tetapi juga harus memiliki pemahaman yang mendalam tentang hakikat manusia, dan masyarakat. Hakikat-hakikat ini akan melandasi pola pikir dan budaya kerja guru, serta loyalitasnya terhadap profesi pendidikan. Demikian halnya dalam pembelajaran, guru harus mampu mengembangkan budaya dan iklim organisasi pembelajaran yang bermakna, kreatif, dan dinamis, bergairah, dialogis, sehingga menyenangkan bagi peserta didik.

Menurut Sofo dalam Nunik Esti Utami, (2012: 16) mengemukakan bahwa "a competency iss composed of skill, knowledge, and attitude, but in particular the consistent applications of those skill, 
knowledge, and attitude to the standard of performance required in employment". Dengan kata lain kompetensi tidak hanya mengandung pengetahuan, keterampilan dan sikap, namun yang penting adalah penerapan dari pengetauan, keterampilan, dan sikap yang diperlukan tersebut dalam pekerjaan.

Kompetensi guru menggambarkan tentang kemampuan yang dituntutkan kepada seseorang yang memangku jabatan sebagai guru. Artinya kemampuan yang ditampilkan itu menjadi ciri keprofesionalannya. Tidak semua kompetensi yang dimiliki seseorang menunjukkan bahwa ia adalah profesional. Ada berbagai variasi kemampuan atau kompetensi yang dimiliki. Kompetensi profesional berpengaruh terhadap gaya mengajar seorang guru, mengajar merupakan suatu proses yang kompleks. Tidak hanya sekedar menyampaikan informasi dari guru kepada siswa. Banyak kegiatan maupun tindakan harus dilakukan, terutama jika diinginkan hasil belajar lebih baik pada seluruh siswa. Kompetensi profesional yang dimiliki oleh seorang guru sangat berperan terhadap proses kegiatan pembelajaran yang terjadi di dalam kelas.

Menurut Kasmawati dalam Halmuniati (2019: 24) mengatakan bahwa kompetensi profesional adalah berbagai kemampuan yang diperlukan agar dapat mewujudkan dirinya sebagai sosok yang profesional. Kompetensi profesional guru sangat diperlukan guna mengembangkan kualitas dan aktivitas tenaga kependidikan dalam hal ini guru. Guru merupakan faktor penentu mutu pendidikan dan keberhasilan pendidikan di sekolah. Guru lebih menguasai konsep/teori dalam materi yang akan disampaikan. Penyampaian materi pun akan menggunakan modelmodel pembelajaran yang inovatif yang dikaitkan dengan kehidupan sehari-hari siswa sehingga akan memberikan dampak yang positif terhadap prestasi belajar. Oleh karena itu, tingkat kompetensi profesional guru disuatu sekolah dapat dijadikan barometer bagi mutu mutu dan keberhasilan pendidikan di sekolah.karakteristik profesionalisme guru bisa ditinjau dari enam komponen, yaitu: 1) Pemahaman dan penerimaan dalam melaksanakan tugas; 2) Kemauan melakukan kerjasama secara efektif dengan peserta didik, guru, orang tua peserta didik, dan masyarakat; 3) Kemampuan mengembangkan visi dan pertumbuhan jabatan secara terus menerus; 4) Mengutamakan pelayanan dalam tugas; 5) Mengarahkan, menekan, dan menumbuhkan pola perilaku peserta didik; 6) Melaksanakan kode etik jabatan.

Meneliti guru sebagai salah seorang pelaksana kegiatan pendidikan di sekolah sangat diperlukan. Tidak jarang ditemukan guru yang kurang memiliki gairah dalam melakukan tugasnya, yang berakibat kurang maksimalnya tujuan yang ingin dicapai. Hal itu disebabkan oleh berbagai faktor, salah satunya adalah kurangnya motivasi kerja guru. Munculnya motivasi sangat berhubungan dengan kompetensi profesional, jika guru merasa sudah berkompeten atas pekerjaannya maka guru akan termotivasi untuk meningkatkan kualitas kerjanya.

Menurut Brown (2010: 72), motivation is the extent to which you make choice about (a) goals to pursue and (b) the effort you will devote to that pursuit. (Motivasi adalah tingkatan dimana seseorang membuat pilihan mengenai (a) tujuan yang hendak dicapai dan (b) usaha yang dilakukan untuk mencapai ujuan). Begitu pula dengan kompetensi yang dimiliki oleh seorang guru, jika guru memiliki kompetensi yang baik maka guru akan berupaya untuk meningkatkan kualitasnya dalam bekerja. Tidak sedikit ditemukan guru yang tidak memiliki kompetensi yang baik, maka motivasi kerja tidak akan terbentuk.

Menurut Zamharil (2017) beberapa faktor yang dapat mempengaruhi karyawan agar dapat mencapai prestasi yang lebih tinggi, yaitu: 1) Faktor ability, secara psikologis, kemampuan terdiri dari kemampuan potensi (IQ) dan kemampuan reality (knowledge dan skill). 2) Faktor motivasi, motivasi diartikan suatu sikap (attitude) pimpinan dan karyawan terhadap situasi kerja (situation) dilingkungan organisasi. Kasmawati dalam Halmuniati (2019: 24) guru yang memiliki motivasi tinggi akan memandang berbagai kekurangan yang ada di sekolah sebagai tantangan. Ia akan berusaha sedapat mungkin untuk mengatasi kekurangan itu. Dengan adanya perhatian yang baik terhadap guru, akan dapat menimbulkan motivasi para guru untuk berbuat yang baik terhadap guru, akan dapat menimbulkan motivasi para guru untuk berbuat yang terbaik dalam melakukan tugas sehingga menumbuhkan komitmen dalam melakukan pekerjaan yang berkualitas dan bertanggungjawab demi kemajuan organisasi.

Sangat disadari bahwa sebagai profesi yang bertugas mendidik, membimbing, dan memberi contoh kepada para siswanya, maka para guru sudah semestinya memiliki motivasi kerja yang 
tinggi agar melalui kinerjanya dapat memberikan manfaat bagi yang membutuhkan yakni para peserta didik. Seorang guru tidak dapat melepaskan diri dari kenyataan bahwa guru adalah individu yang mempunyai kebutuhan, keinginan, dan harapan dari tempat bekerjanya. Hal ini berkaitan erat dengan kualitas hasil kerja guru itu sendiri yang sesungguhnya dipengaruhi oleh motivasi kerja masing-masing individu.

Motivasi tidak dapat diamati secara langsung, tetapi dapat diintepretasikan dari tingkah lakunya. Motivasi kerja merupakan dorongan untuk melakukan segala sesuatu yang lebih baik dari lainnya di dalam melakukan kegiatan untuk mencapai tujuan. Motivasi kerja guru dapat dipengaruhi oleh beberapa faktor antara lain kompetens profesional. Berdasarkan faktor tersebut penulis mengajukan judul "Pengaruh Kompetensi Profesional terhadap Motivasi Kerja Guru SD di Gugus Rujakbeling Kecamatan Kebumen Kabupaten Kebumen ".

\section{METODE PENELITIAN}

Jenis penelitian yang digunakan dalam penelitian ini adalah penelitian kuantitatif. Menurut Sugiono $(2018 ; 8)$ metode penelitian kuantitatif dapat diartikan sebagai metode penelitian yang berlandaskan pada filsafat positivism, digunakan untuk meneliti pada populasi atau sampel tertentu, pengumpulan data menggunakan instrument penelitian, analisis data bersifat kuantitatif statistik, dengan tujuan untuk menguji hipotesis yang telah di tetapkan. Dikatakan penelitian kuantitatif dikarenakan data dalam penelitian ini berupa angka.

Lokasi penelitian dilakasanakan di Sekolah Dasar gugus Rujakbeling Kecamatan Kebumen, Kabupaten Kebumen, Provinsi Jawa Tengah. Populasi dalam penelitian ini adalah guru Sekolah Dasar di gugus Rujakbeling Kecamatan Kebumen, Kabupaten Kebumen, Provinsi Jawa Tengah yang terdiri dari 5 sekolah dasar diantaranya 1 sekolah inti yaitu SD Negeri 1 Kebumen dengan jumlah guru 9, dan 4 sekolah dasar imbas yaitu SD Negeri 2 Kebumen dengan jumlah guru 7; SD Negeri 5 Kebumen dengan jumlah guru 8; SD Negeri 7 Kebumen dengan junlah guru 6 dan terakhir SD Kristen Penabur Kebumen dengan jumlah guru 11. Berdasarkan data tersebut populasi dalam penelitian ini sebesar 41 guru. Sampel dalam penelitian ini sebesar 41 guru, atau seluruh populasi dijadikan sebagai sampel penelitian, sehingga dapat dikatakan bahwa penelitian ini adalah penelitian populasi. Teknik pengambilan data dalam penelitian ini menggunakan angket, angket mengenai kompetensi professional dan angket mengenai motivasi kerja guru. Adapun kisi instrument penelitian ini adalah sebagai berikut:

Tabel 1. Kisi-kisi Instrumen Variabel

Kompetensi

\begin{tabular}{|c|c|c|c|c|}
\hline $\begin{array}{l}\text { Vari } \\
\text { abel }\end{array}$ & Aspek & Indikator & $\begin{array}{c}\text { No } \\
\text { Butir }\end{array}$ & JML \\
\hline \multirow{11}{*}{$\begin{array}{l}\text { Kom } \\
\text { pete } \\
\text { nsi } \\
\text { Guru }\end{array}$} & \multirow{5}{*}{$\begin{array}{l}\text { Kompetensi } \\
\text { Pedagogik }\end{array}$} & $\begin{array}{l}\text { Memanfaatkan } \\
\text { teknologi informasi dan } \\
\text { komunikasi }\end{array}$ & 1,21 & 2 \\
\hline & & $\begin{array}{l}\text { Menyelenggarakan } \\
\text { penilaian dan evaluasi } \\
\text { proses dan hasil belajar }\end{array}$ & 2,8 & 2 \\
\hline & & $\begin{array}{l}\text { Melakukan tindakan } \\
\text { reflektif }\end{array}$ & 20,25 & 2 \\
\hline & & $\begin{array}{l}\text { Berkomunikasi secara } \\
\text { efektif, empatik, dan } \\
\text { santun dengan siswa }\end{array}$ & 5,22 & 2 \\
\hline & & $\begin{array}{l}\text { Menyelenggarakan } \\
\text { kegiatan } \\
\text { pengembangan yang } \\
\text { mendidik }\end{array}$ & 6,7 & 2 \\
\hline & \multirow{2}{*}{$\begin{array}{l}\text { Kompetensi } \\
\text { Kepribadian }\end{array}$} & $\begin{array}{l}\text { Bertindak sesuai } \\
\text { dengan norma agama, } \\
\text { hukum, sosial, dan } \\
\text { kebudayaan nasional } \\
\text { Indonesia }\end{array}$ & $\begin{array}{c}3,9 \\
11\end{array}$ & 3 \\
\hline & & $\begin{array}{l}\text { Menampilkan diri } \\
\text { sebagai pribadi yang } \\
\text { jujur, berakhlak mulia, } \\
\text { dan teladan bagi siswa } \\
\text { dan masyarakat. }\end{array}$ & 10,12 & 2 \\
\hline & \multirow{2}{*}{$\begin{array}{l}\text { Kompetensi } \\
\text { Profesional }\end{array}$} & $\begin{array}{l}\text { Menguasai materi, } \\
\text { struktur, konsep, dan } \\
\text { pola pikir mata } \\
\text { pelajaran yang diampu }\end{array}$ & 13,17 & 2 \\
\hline & & $\begin{array}{l}\text { Mengembangkan } \\
\text { keprofesionalan dalam } \\
\text { mengajar }\end{array}$ & $\begin{array}{c}14 \\
15,18\end{array}$ & 3 \\
\hline & \multirow{3}{*}{$\begin{array}{l}\text { Kompetensi } \\
\text { Sosial }\end{array}$} & $\begin{array}{l}\text { Bertindak obyektif dan } \\
\text { tidak diskriminatif }\end{array}$ & 16,19 & 1 \\
\hline & & $\begin{array}{l}\text { Berkomunikasi dengan } \\
\text { santun }\end{array}$ & $\begin{array}{c}4,23 \\
24\end{array}$ & 3 \\
\hline & & Jumlah & & 25 \\
\hline
\end{tabular}

Tabel 2. Kisi-kisi Instrumen Variabel Motivasi Kerja Guru

\begin{tabular}{clcc}
\hline No & \multicolumn{1}{c}{ Indikator } & Nomor & JML \\
\hline 1. & Pendapatan yang layak & $1,3,17$ & 3 \\
\hline 2. & Kesempatan untuk maju & $4,2,21$ & 3 \\
\hline 3. & Memperoleh pengakuan & $5,7,22$ & 3 \\
\hline 4. & Lingkungan kerja yang baik & $6,8,18,25$ & 4 \\
\hline 5. & Penerimaan oleh kelompok & $9,11,23$ & 3 \\
\hline 6. & Penghargaan atas prestasi & $10,16,24$ & 3 \\
\hline 7. & Disiplin & $12,15,19$ & 3 \\
\hline 8. & Pimpinan yang mendukung & $13,14,20$ & 3 \\
\hline \multicolumn{4}{r}{ Jumlah } \\
\hline
\end{tabular}

Data dalam angket kompetensi professional dan motivasi kerja guru berbentuk skala Likert 14 dengan jawaban Selalu (SL) dengan sekor 4, Sering (SR) dengan skor 3, Kadang-Kadang (KD) dengan skor 2, dan Tidak Pernah (TP) dengan skor 1. Dimana angket kompetensi profesiona- 
lisme dan motivasi kerja guru masing-masing terdiri dari 25 butir pernyataan. Uji coba instrument dalam penelitian ini menggunakan uji validitas dengan teknik analisis Product Moment dan uji reliabilitas menggunakan Alpha Cronbach. Uji coba instrument dilakukan kepada 20 responden dengan taraf kesalahan 5\% sehingga diketahui $r$ tabel nya sebesar 0,444 . Adapun hasil uji validitas instrumen dengan bantuan SPSS 25.0 sebagai berikut:

Tabel 3. Hasil Uji Validitas Angket Kompetensi Profesional Guru

\begin{tabular}{cccc}
\hline No. & r Hitung & r Tabel & Keterangan \\
\hline 1 & 0,843 & 0,444 & Valid \\
\hline 2 & 0,763 & 0,444 & Valid \\
\hline 3 & 0,832 & 0,444 & Valid \\
\hline 4 & 0,589 & 0,444 & Valid \\
\hline 5 & 0,624 & 0,444 & Valid \\
\hline 6 & 0,680 & 0,444 & Valid \\
\hline 7 & 0,901 & 0,444 & Valid \\
\hline 8 & 0,854 & 0,444 & Valid \\
\hline 9 & 0,617 & 0,444 & Valid \\
\hline 10 & 0,786 & 0,444 & Valid \\
\hline 11 & 0,858 & 0,444 & Valid \\
\hline 12 & 0,760 & 0,444 & Valid \\
\hline 13 & 0,867 & 0,444 & Valid \\
\hline 14 & 0,763 & 0,444 & Valid \\
\hline 15 & 0,744 & 0,444 & Valid \\
\hline 16 & 0,773 & 0,444 & Valid \\
\hline 17 & 0,819 & 0,444 & Valid \\
\hline 18 & 0,854 & 0,444 & Valid \\
\hline 19 & 0,595 & 0,444 & Valid \\
\hline 20 & 0,923 & 0,444 & Valid \\
\hline 21 & 0,696 & 0,444 & Valid \\
\hline 22 & 0,684 & 0,444 & Valid \\
\hline 23 & 0,639 & 0,444 & Valid \\
\hline 24 & 0,739 & 0,444 & Valid \\
\hline 25 & 0,786 & 0,444 & Valid \\
\hline & & & \\
\hline
\end{tabular}

Tabel 4. Hasil Uji Validitas Angket Motivasi Kerja Guru

\begin{tabular}{cccc}
\hline No. & r Hitung & r Tabel & Keterangan \\
\hline 1 & 0,870 & 0,444 & Valid \\
\hline 2 & 0,876 & 0,444 & Valid \\
\hline 3 & 0,672 & 0,444 & Valid \\
\hline 4 & 0,605 & 0,444 & Valid \\
\hline 5 & 0,584 & 0,444 & Valid \\
\hline 6 & 0,584 & 0,444 & Valid \\
\hline 7 & 0,876 & 0,444 & Valid \\
\hline 8 & 0,699 & 0,444 & Valid \\
\hline 9 & 0,703 & 0,444 & Valid \\
\hline 10 & 0,626 & 0,444 & Valid \\
\hline 11 & 0,822 & 0,444 & Valid \\
\hline 12 & 0,644 & 0,444 & Valid \\
\hline 13 & 0,499 & 0,444 & Valid \\
\hline 14 & 0,641 & 0,444 & Valid \\
\hline 15 & 0,790 & 0,444 & Valid \\
\hline 16 & 0,797 & 0,444 & Valid \\
\hline 17 & 0,797 & 0,444 & Valid \\
\hline 18 & 0,648 & 0,444 & Valid \\
\hline 19 & 0,692 & 0,444 & Valid \\
\hline 20 & 0,687 & 0,444 & Valid \\
\hline 21 & 0,870 & 0,444 & Valid \\
\hline 22 & 0,876 & 0,444 & Valid \\
\hline 23 & 0,876 & 0,444 & Valid \\
\hline 24 & 0699 & 0,444 & \\
\hline & & & \\
\hline
\end{tabular}

\begin{tabular}{cccc}
\hline No. & r Hitung & r Tabel & Keterangan \\
\hline 25 & 0,790 & 0,444 & Valid \\
\hline
\end{tabular}

Berdasarkan uji validitas menggunakan correlation product moment dengan bantuan SPSS 25.0 menunjukkab bahwa instrumen angket kompetensi profesional guru dan motivasi kerja guru semuanya valid dan dapat digunakan dalam penelitian ini. Uji Reliabilitas instrumen penelitian ini menggunakan uji Cronbach's Alpha. Butir soal dikatakan reliabel jika Cronbach's Alpha lebih besar dari 0.6 dan tidak reliabel jika Cronbach's Alpha lebih kecil dari 0,6 (Haryadi Sarjono \& Winda Julianita, 2011: 45). Berikut ini hasil dari pengujian reliabilitas menggunakan program SPSS 16.0 for windows.

Tabel 5. Hasil Uji Reliabilitas Angket Kompetensi Profesional

\begin{tabular}{r|c|r}
\hline \multicolumn{3}{|c|}{ Reliability Statistics } \\
\hline Cronbach's Alpha & $\begin{array}{c}\text { Cronbach's Alpha Based on } \\
\text { Standardized Items }\end{array}$ & N of Items \\
\hline .967 & .970 & 25 \\
\hline
\end{tabular}

Tabel 6. Uji Reliabilitas Angket Motivasi Kerja Guru

\begin{tabular}{r|r|r}
\hline \multicolumn{3}{|c}{ Reliability Statistics } \\
\hline Cronbach's Alpha & $\begin{array}{c}\text { Cronbach's Alpha Based on } \\
\text { Standardized Items }\end{array}$ & $\begin{array}{c}\mathrm{N} \text { of } \\
\text { Items }\end{array}$ \\
\hline .958 & .962 & 25 \\
\hline
\end{tabular}

Dengan melihat tabel Reliability Statistics kuesioner variable kompetensi profesional guru, diketahui nilai Cronbach's Alpha adalah sebesar 0.976 dan jumlah item pertanyaan adalah 25, dengan demikian dapat diambil kesimpulan bahwa kuesioner tersebut reliabel karena 0.976 $>0.60$. dan kuesioner variable motivasi kerja guru, diketahui nilai Cronbach's Alpha adalah sebesar 0.958 dan jumlah item pertanyaan adalah 25, dengan demikian dapat diambil kesimpulan bahwa kuesioner tersebut reliabel karena $0.958>0.60$. Teknik analisis dalam penelitian ini dengan cara melakukan uji analisis prasyarat dan uji regresi. Uji analisis prasyarat yang meliputi: uji linieritas dan uji normalitas. Uji analisis regresi dengan melakukan persamaan uji regresi, uji t, dan $\mathrm{R}$ Square.

\section{HASIL DAN PEMBAHASAN}

\section{A. Hasil Penelitian}

1. Uji Normalitas Data

Pengujian pengaruh kompetensi profesional terhadap motivasi kerja guru dilakukan dengan menggunakan analisis regresi linier sederhana. Sebelum melaakukan uji analisis regresi sederhana dilakukan uji normalitas terlebih dahulu, dalam penelitian ini 
pengujian normalitas menggunakan rumus Kolmogorov-Smirnov, hal ini untuk mengetahui apakah suatu data berdistribusi norma jika signifikaan (significance level) lebih dari 0,05 (sign $>0,05$ )

Tabel 7. Uji Normalitas

\begin{tabular}{|l|r|r|}
\hline \multicolumn{2}{|c|}{ One-Sample Kolmogorov-Smirnov Test } \\
\hline \multirow{2}{|l|}{} & Unstandardized Residual \\
\hline N & & 41 \\
\hline \multirow{2}{*}{ Mormal Parameters $\mathrm{a}, \mathrm{b}$} & Mean & .0000000 \\
\cline { 2 - 3 } & Std. Deviation & 9.42752656 \\
\hline Differences & Absolute & .117 \\
\cline { 2 - 3 } & Positive & .074 \\
\cline { 2 - 3 } & Negative & .117 \\
\hline Test Statistic & .117 \\
\hline Asymp. Sig. (2-tailed) & $.177 \mathrm{c}$ \\
\hline \multicolumn{2}{|l|}{ a. Test distribution is Normal. } \\
\hline b. Calculated from data. \\
\hline \multicolumn{2}{|l|}{ c. Lilliefors Significance Correction. } \\
\hline
\end{tabular}

Sesuai dengan tabel diatas dapat dilihat nilai sig (2-tilled) Kolmogorov-Smirnov sebesar 0,177. Karena sign $>0,05$ dapat disimpulkan bahwa distribusi data diperoleh normal. Hal ini menunjukkan bahwa variabel kompetensi profesional dengan motivasi kerja guru dalam penelitian ini berdistribusi normal.

\section{Uji Linieritas Data}

Dilakukannya pengujian linieritas bertujuan untuk mengetahui variabel bebas dan variabel terikat mempunyai hubungan linier atau tidak mempunyai hubungan. Untuk mengetahui ada hubungan linier atau tidak dengan mencari tau nilai Deviation from Linearity Sig dari variabel bebas dan terikat. Jika nilai sig > 0,05 maka dapat dinyatakan kedua variabel bebas dan terikat mempunyai hubungan yang linier, begitu juga sebaliknya apabila nilai sig < 0,05 maka berarti kedua variabel tersebut tidak linier. Hasil dari perhitungan uji linieritas dari penelitian ini sebagai berikut:

Tabel 8. Uji Linieritas

\begin{tabular}{|c|c|c|c|c|c|c|c|}
\hline \multicolumn{8}{|c|}{ ANOVA Table } \\
\hline & & & $\begin{array}{c}\text { Sum of } \\
\text { Squares }\end{array}$ & $\mathrm{df}$ & $\begin{array}{l}\text { Mean } \\
\text { Square }\end{array}$ & $\mathrm{F}$ & Sig. \\
\hline \multirow{5}{*}{$\begin{array}{l}\text { motiva } \\
\text { si kerja } \\
\text { guru } \\
\text { kompe } \\
\text { tensi } \\
\text { profesi } \\
\text { onal }\end{array}$} & \multirow{3}{*}{$\begin{array}{l}\text { Be } \\
\text { tw } \\
\text { ee } \\
\text { n } \\
\mathrm{Gr} \\
\text { ou } \\
\text { ps }\end{array}$} & $\begin{array}{l}\text { (Co } \\
\text { mbi } \\
\text { ned) }\end{array}$ & $\begin{array}{r}2256 . \\
280\end{array}$ & 23 & 98.099 & .868 & .630 \\
\hline & & $\begin{array}{l}\text { Line } \\
\text { arity }\end{array}$ & $\begin{array}{r}621.6 \\
50\end{array}$ & 1 & 621.650 & $\begin{array}{r}5.50 \\
3\end{array}$ & .031 \\
\hline & & $\begin{array}{l}\text { Devi } \\
\text { ation } \\
\text { from } \\
\text { Line } \\
\text { arity }\end{array}$ & $\begin{array}{r}1634 . \\
630\end{array}$ & 22 & 74.301 & .658 & .824 \\
\hline & \multicolumn{2}{|c|}{$\begin{array}{l}\text { Within } \\
\text { Groups }\end{array}$} & $\begin{array}{r}1920 . \\
500\end{array}$ & 17 & 112.971 & & \\
\hline & \multicolumn{2}{|c|}{ Total } & $\begin{array}{r}4176 . \\
780\end{array}$ & 40 & & & \\
\hline
\end{tabular}

Berdasarkan hasil uji linieritas di atas diketahui nilai Deviation from Linearity Sig. adalah 0,824. Berarti nilai tersebut lebih besar dari 0,05 dan dapat dinyatakan bahwa kedua variabel tersebut membunyai hubungan linier atau dapat disebut bahwa variabel kompetensi profesional dan motivasi kerja guru mempunyai hubungan linier.

3. Analisis Regresi Sederhana

a. Persamaan Regresi Sederhana

Tujuan dari analisis ini merupakan untuk menguji ada tidaknya pengaruh terhadap variabel bebas dengan variabel terikat, cara mengetahui ada tidaknya pengaruh dengan membandingkan $t$ hitung dengan $t$ tabel. Variabel bebas dan variabel terikat dinyatakan berpengaruh jika t hitung lebih besar dari pada $t$ tabel, tetapi sebaliknya jika t hitung lebih rendah dari pada $t$ tabel maka dinyataakan variabel bebas dan variabel terikat tidak mempunyai pengaruh, Dasar untuk memba-ndingkan nilai signifikansi jika nilai sig. kurang dari 0,05 maka bisa dinyatakan variabel bebas berpengaruh dengan variabel terikat, tetapi jika nilai sig. Lebih dari 0,05 maka variabel bebas dinyatakan tidak berpengaruh dengan variabel terikat. Uji regresi sederhana dilakukan dengan persamaan:

$\mathrm{Y}=\mathrm{a}+\mathrm{bX}$

Keterangan:

$\mathrm{Y}=$ variabel terikat

$\mathrm{a}=$ konstanta regresi

$\mathrm{bX}=$ nilai turunan atau peningkatan variabel bebas.

Tabel 9. Hasil Uji Regresi

\begin{tabular}{|c|c|c|c|c|c|c|}
\hline \multicolumn{7}{|c|}{ Coefficients $^{a}$} \\
\hline \multirow{2}{*}{\multicolumn{2}{|c|}{ Model }} & \multicolumn{2}{|c|}{\begin{tabular}{|c|}
$\begin{array}{c}\text { Unstandardized } \\
\text { Coefficients }\end{array}$ \\
\end{tabular}} & \multirow{2}{*}{$\begin{array}{c}\text { Standardized } \\
\text { Coefficients } \\
\text { Beta }\end{array}$} & \multirow[b]{2}{*}{$\mathrm{t}$} & \multirow[b]{2}{*}{ Sig. } \\
\hline & & B & $\begin{array}{l}\text { Std. } \\
\text { Error }\end{array}$ & & & \\
\hline 1 & (Constant) & 31.641 & 12.073 & & 2.621 & .012 \\
\hline & $\begin{array}{l}\text { kompetensi } \\
\text { profesional }\end{array}$ & .468 & .179 & .386 & 2.611 & .013 \\
\hline
\end{tabular}

Dari hasil uji diatas maka dapat dibentuk persamaan regresi sebagai berikut:

$\mathrm{Y} 1=\mathrm{a}+\mathrm{bX}$

$\mathrm{Y} 1=31,641+0,468(\mathrm{X})$

Berdasarkan hasil dari constant (a) sebesar 31,641 sedangkan nilai dari kompetensi profesional adalah 0,468. Hasil tersebut dapat diartikan bahwa nilai koefisien regresi dari variabel $\mathrm{X}$ adalah 0,468 . setiap penambahan $1 \%$ nilai kompetensi 
profesional, Maka nilai dari motivasi kerja guru bertambah besar dan koefisien regresi tersebut bernilai positif. Sehingga dapat dinyatakan bahwa variabel $X$ dengan variabel Y1 berpengaruh positif. Dari hasil uji diatas diketahui nilai signifikan adalah 0,013 lebih kecil dari nilai probabilitasn yaitu 0,05 sehingga dapat dinyatakan bahwa variabel kompetensi profesional (X) berpengaruh signifikan terhadap motivasi kerja guru (Y) di SD Gugus Rujakbeling Kecamatan Kebumen Kabupaten Kebumen.

b. Analisis Uji t

Penelitian ini menggunakan uji $t$ yang bertujuan untuk mengetahui bagaimana pengaruh antara variable independen (X) secara sendiri (parsial) dengan variabel dependen (Y). Pengambilan keputusan untuk mengetahui pengaruhnya ada dua cara sebagai berikut:

1) Berdasarkan hasil dari nilai t hitung yang berdasarkan dari t tabel. Variabel independen dinyatakan secara parsial berpengaruh terhadap variabel dependen jika nilai $t$ hitung $>t$ tabel. Sebaliknya, jika t hitung $<\mathrm{t}$ tabel maka variabel independen dinyatakan secara parsial tidak berpengaruh terhadap variabel dependen.

2) Berdasarkan hasil dari nilai signifikansi, Variabel independen dinyatakan secara parsial berpengaruh signifikan terhadap variabel dependen jika nilai signifikansi kurang dari 0,05. Sebaliknya, jika hasil nilai signifikansi lebih dari 0,05 maka variabel independen secara parsial dinyatakan tidak berpengaruh signifykan terhadap variabel dependen.

Berdasarkan hasil pengujian regresi pada tabel 9 dari perhitungan uji $t$ di atas dapat diketahui:

1) Diketahui variabel perhatian orang tua mendapatkan nilai $t$ hitung sebesar 2,611 dan dengan $t$ tabel adalah derajat bebas $(\mathrm{df})=\mathrm{n}-\mathrm{k}$ atau $41-2=39$ diperoleh nilai t tabel sebesar 2,023. Hal tersebut menunjukkan bahwa thitung $>$ dari t tabel $(2,611>2,023)$ yang berarti bahwa terdapat pengaruh kompetensi profesional $(\mathrm{X})$ berpengaruh signifikan terhadap motivasi kerja guru (Y) di SD Gugus Rujakbeling Kecamatan Kebumen Kabupaten Kebumen.

2) Diketahui nilai signifikansi sebesar 0,013 kurang dari 0,05 bisa disimpulkan bahwa variabel kompetensi profesional secara parsial berpengaruh terhadap motivasi kerja guru di SD Gugus Rujakbeling Kecamatan Kebumen Kabupaten Kebumen.

c. Analisis Koefisien Determinasi

Penelitian ini membutuhkan analisis koefisien determinasi untuk mengetahui seberapa besar variasi variabel bebas bisa menjelaskan seluruh varian dari variabel terikat. Nilai koefisien determinasi yaitu antara 0 sampai dengan 1 . Jika $\mathrm{R}=0$ maka tidak ada hubungan antara variabel independent (bebas) dengan variabel dependent (terikat). Sebaliknya, jika $\mathrm{R}=1$ maka terdapat hubungan yang kuat antara variabel independent dengan variabel dependent. Berikut hasil pengujian koefisien determinasi:

Tabel 10. Hasil Koefisien Determinasi

\begin{tabular}{|c|c|c|c|c|}
\hline \multicolumn{5}{|c|}{ Model Summaryb } \\
\hline Model & $\mathrm{R}$ & R Square & $\begin{array}{l}\text { Adjusted R } \\
\text { Square }\end{array}$ & $\begin{array}{l}\text { Std. Error of the } \\
\text { Estimate }\end{array}$ \\
\hline 1 & $.386^{\mathrm{a}}$ & .149 & .127 & 9.548 \\
\hline \multicolumn{5}{|c|}{ a. Predictors: (Constant), kompetensi profesional } \\
\hline \multicolumn{5}{|c|}{ b. Dependent Variable: motivasi kerja guru } \\
\hline
\end{tabular}

Berdasarkan hasil dari tabel diatas nilai $\mathrm{R}$ sebagai koefisien korelasi adalah 0,386 sedangkan diketahui $\mathrm{R}$ square sebagai koefisien determinasi ialah 0,149. Hasil tersebut dapat menunjukkan seberapa besarnya pengaruh variabel independent secara menyeluruh terhadap naik turunnya variabel dependent. Dapat dijelaskan bahwa variabel independent (kompetensi profesional) mempunyai kemampuan sebesar $14,9 \%$ dalam mempengaruhi varians terhadap variabel dependent (motivasi kerja guru) dan masih ada $100 \%-14,9 \%=84,1 \%$ dipengaruhi variabel lain.

\section{B. Pembahasan}

Berdasarkan hasil dari pengujian yang sudah dilakukan terhadap variabel kompetensi profesional dengan varibel motivasi kerja guru pengaruh yang ditimbulkan adalah pengaruh positif atau bisa di sebut variabel kompetensi profesional mempunyai pengaruh terhadap variabel motivasi kerja guru, seperti hasil uji t kompetensi profesional mendapatkan nilai $t$ hitung sebesar 2,611 dan dengan t tabel adalah derajat bebas $(\mathrm{df})=\mathrm{n}-\mathrm{k}$ atau $41-2=39$ diperoleh nilai t tabel sebesar 2,023. Hal tersebut menunjukkan bahwa $\mathrm{t}$ hitung $>$ dari $\mathrm{t}$ tabel $(2,611>2,023)$ yang berarti bahwa terdapat 
pengaruh kompetensi profesional terhadap motivasi kerja guru.

$\mathrm{R}$ square sebagai koefisien determinasi ialah 0,149. Hasil tersebut dapat menunjukkan seberapa besarnya pengaruh variabel independent secara menyeluruh terhadap naik turunnya variabel dependent. Dapat dijelaskan bahwa variabel independent (kompetensni profesional) mempunyai kemampuan sebesar $14,9 \%$ dalam mempengaruhi varians terhadap variabel dependent (motivasi kerja guru) dan masih ada $100 \%-14,9 \%=84,1 \%$ dipengaruhi variabel lain.

Berdasarkan hasil penelitian diatas mendukung penelitian terdahulu yang dilaksanakan oleh Suardana, dkk (2018:58) yang menyatakan bahwa motivasi kerja guru juga dipengaruhi oleh faktor kompetensi professional. Kompetensi guru merupakan seperangkat pengetahuan, keterampilan, dan perilaku yang harus dimiliki, dihayati, dikuasai, dan diaktualisasikan oleh guru dalam melaksanakan tugas keprofesionalan. Berdasarkan Peraturan Pemerintah (PP) Nomor 18 Tahun 2007 tentang guru, dinyatakan bahwasanya kompetensi yang harus dimiliki oleh Guru meliputi kompetensi profesional, kompetensi kepribadian, kompetensi sosial, dan kompetensi pedagogik yang diperoleh melalui pendidikan profesi. Kompetensi guru tersebut bersifat menyeluruh dan merupakan satu kesatuan yang satu sama lain saling berhubungan dan saling mendukung. Kompetensi profesional yang dimaksud antara lain kemampuan pemahaman tentang peserta didik secara mendalam dan penyelenggaraan pembelajaran yang mendidik. Pemahaman tentang peserta didik meliputi pemahaman tentang psikologi perkembangan anak, sedangkan pembelajaran yang mendidik meliputi kemampuan merancang pembelajaran, mengimple-mentasikan pembelajaran, menilai proses dan hasil pembelajaran, dan melakukan perbaikan secara berkelanjutan.

Penelitian ini juga mendukung penelitian sebelumnya yang dilakukan oleh Halmuniati (2019: 32) menunjukkan bahwa pengaruh kompetensi profesional guru terhadap motivasi kerja dapat dibuktikan dengan nilai estimate koefisien jalur yang menunjukkan adanya pengaruh positif dan signifikan. Hasil pengujian membuktikan bahwa semakin baik kompetensi profesional guru, maka motivasi kerja semakin meningkat. Artinya peningkatan kompetensi profesional guru searah dan nyata terhadap peningkatan motivasi kerja, dengan kata lain hasil penelitian ini mencerminkan bahwa kompetensi profesional guru yang baik mampu mendukung perubahan pada peningkatan motivasi kerja.

\section{SIMPULAN DAN SARAN}

\section{A. Simpulan}

Terdapat pengaruh pengaruh kompetensi profesional terhadap motivasi kerja guru SD di Gugus Rujakbeling Kecamatan Kebumen Kabupaten Kebumen dengan $\mathrm{t}$ hitung $>$ dari $\mathrm{t}$ tabel $(2,611>2,023)$ dan besarnya pengaruhnya sebesar $14,9 \%$ diketahui dari $\mathrm{R}$ Square sebesar 0,149 .

\section{B. Saran}

Berdasarkan hasil penelitian dan pembahasan di atas, dapat disampaikan saran sebagai berikut:

1. Bagi Guru

Guru hendaknya senantiasa meningkatkan kompetensi melalui berbagai cara. Cara yang dilakukan seperti mengikuti seminar maupun work shop ataupun bisa juga melalui membaca banyak buku sehingga memiliki banyak referensi bagaimana cara untuk meningkatkan kompetensi sehingga guru memiliki motivasi untuk bekerja karena tidak akan memiliki kesulitan dalam mengemban tugasnya.

2. Bagi Kepala Sekolah

Kepala sekolah hendaknya memberikan pengawasan serta motivasi kepada guru agar guru memiliki dorongan dari dalam diri untuk senantiasa meningkatkan kemampuannya. Menciptakan iklim kerja yang kondusif agar guru merasa nyaman dalam bekerja, menciptakan komunikasi yang baik dan hangat antara guru dan kepala sekolah, memberikan kesempatan kepada guru untuk maju baik dalam pendidikan maupun dalam hal jabatannya.

\section{DAFTAR RUJUKAN}

Brown. 2010. Teaching by Priciples: An Interactive Approach to Language Pedagogy. New York: addisiion Wessley Lengman, Inc.

Halmuniati, H., \& Sabania, S. (2019). Pengaruh Kompetensi Profesional Terhadap Motivasi Kerja Guru Honorer Tk Se Kecamatan Kendari Barat Kota Kendari. Shautut Tarbiyah, 25(1), 19-36.

Nunik Esti Utami. 2012. Pengaruh Kompetensi Guru dan Perhatian Orang Tua Terhadap Prestasi Belajar Siswa Mata Pelajaran 
Sejarah di Kelas XII SMA Muhammadiyah 2 Yogyakarta Tahun Pelajaran 2011/2012. Yogyakarta: Universitas PGRI Yogyakarta.

Suardana, I. P., Yudana, M., \& Agung, A. A. G. (2018). Kontribusi Gaya Kepemimpinan, Kompetensi Profesional, dan Kompetensi Manajerial Kepala Sekolah Terhadap Motivasi Kerja Guru (Studi Tentang Persepsi Guru SMAN 1 Mengwi). Jurnal Administrasi Pendidikan Indonesia, 9(1), 55-66.
Sugiyono. 2018. Metode Penelitian Pendidikan Pendekatan Kuantitatif, Kualitatif, dan R\&D. Bandung: Alfabeta.

Zamharil Yahya dan Fitri Hidayati. 2017. Analisis Kompetensi Terhadap Penilaian Kinerja Dosen (Studi Kasus Dosen UIN Sultan Syarif Kasim Riau). Jurnal Penelitian sosial keagamaan, Vol.17, No.1 